\title{
Kanada, Bulgaristan ve Türkiye Öğretmen Yetiştirme, Eğitim Yönetimi ve Denetimi Sistemlerinin Karşılaştırılması
}

\section{Tuba Yavuzkurt*}

Aydın Adnan Menderes Üniversitesi

Ĕ̆itim Fakültesi, Doktora Öğrencisi orcid.org/0000-0002-3109-4199

\section{Bilgen Kiral}

Aydın Adnan Menderes Üniversitesi

Ĕ̆itim Fakültesi

orcid.org/0000-0001-5352-8552

\section{Öz}

Bu çalışma; Kanada, Bulgaristan ve Türkiye öğretmen yetiştirme, eğitim yönetimi ve denetimi sistemlerini karşılaştırmak, benzer ve farkl yönlerini ortaya koymak amacıyla yapılmıştır. Araştırmada nitel araştırma yöntemi benimsenmiş olup; karşılaştırmalı tarama yöntemi kullanılmıştır. Ülkelerin eğitim yönetimi sistemleri incelendiğinde; Kanada'nın bölgesel, eyaletlere göre değişen bir eğitim yönetimi yapısı olduğu ve her eyaletin eğitim bakanlı̆̆ı olduğu; Bulgaristan ve Türkiye'nin ise merkezi yönetime sahip olduğu ve eğitimden sorumlu birer Bakanlik tarafindan yönetildiği tespit edilmiştir. Ülkelerin yönetici olma sistemleri incelendiğinde Kanada'da okul yöneticisi olmak için yüksek lisans yapmış olmak veya yönetici yeterlikleri programın tamamlamış olmak gerekmektedir. Bulgaristan'da da yönetici olabilmek için Kanada da olduğu gibi öğretmenlerin yüksek lisans yapmış olmaları gerekmektedir. Türkiye'de ise yönetici olmak için bakanlık tarafından yapılan sınavları geçmiş olmak yeterlidir. Ülkelerin eğitim denetimi sistemleri incelendiğinde Kanada ve Türkiye'de öğretmenlerin okul müdürlerince,

Yayın Geliș Tarihi 12.07.2019

Yayın Kabul Tarihi 04.09.2019
Bulgaristan'da ise bakanlık birimi bünyesindeki müfettişler tarafindan denetimlerin yapıldığ sonucuna ulaşılmıştır.

Anahtar Sözcükler: Karşılaştırma, Öğretmen Yetiştirme Sistemi, Ĕ̆itim Yönetimi ve Denetimi.

\section{Comparison of Teacher Training, Educational Administration and Supervision Systems in Canada, Bulgaria and Turkey}

\section{Abstract}

This study has been done to the purpose of the revealing the similarities and differences by comparing Canada's, Bulagaria's and Turkey's teacher training, educational administration and supervision systems. Qualitative research method was adopted in the research; comperative scanning method was used. When the educational administration systems of countries are examined; Canada has a regional, changing educational administration structure from state-tostate and each state has its own ministery of education; on the other hand, it has been detected that in Bulgaria and Turkey there has been centralized management and each one is managed by ministery that is responsible for education. When the countries administration systems are examined, it is necessary to have a master's degree or to have comleted the executive qualifications program in order to become an education administrator in Canada. In order to become an administrator in Bulgaria, teachers must have a master's degree as in Canada. In Turkey, in order to become an administrator it is sufficent to pass the exams which are conducted by ministery. When the educational supervision systems of the countries are examined; it is concluded that, in Canada and Turkey the teachers have beeen supervised by the school administrators but in Bulgaria they have been supervised by the inspectors who are exist within the structure of ministery.

Keywords: Comparison, Teacher Training System, Educational Administration and Supervision. 


\section{Giriş}

Bir ulusun en önemli yapı taşı, eğitimli insan gücü diğer bir değişle insan sermayesidir. Aydınlanma dönemini ve sanayi devrimini önce yaşamış, Reform ve Rönesans'ı erkenden tamamlamış uluslar kısa sürede bilginin ne denli özel bir güç olduğunu hemen kavramışlardır. Bu erken uyanış öncelikle makinayı kullananı eğitmenin gereğiyle, eğitimli insan gücü üretmeye bu ulusları itmiştir. Özellikle 21. yüzyılda artık önemli olan, makinayı kullanmayı bilen değil; bilgi ve iletişim teknolojilerini üretecek ve kullanacak iş gücüne sahip olmaktır. Vizyonu geniş, yaratıcılığı fazla, her türden okuryazarlığa sahip (resim, müzik, medya vb.) bireylerden oluşan bir toplum geleceğin daha da olumsuzlaşacak kapitalist güçleriyle ancak mücadele edebilir. Bu insanı yetiştirecek olan da hiç kuşkusuz eğitim sistemidir. Bu sistem öyle olmalıdır ki bireyler bu sistemden en üst düzeyde faydalanıp çağın gereklerini yakalasın ve aynı zamanda mutlu bireyler de olabilsinler. Küreselleşen Dünya ile doğu ile batının, kuzeyle güneyin birbirine daha da yakınlaşması dolayısı ile dünyada tüm sistemlerde olduğu gibi eğitim sistemlerinde de bir etkileşim söz konusudur. Farklı toplumlardaki eğitim sistemlerinin özelliklerini öğrenmek ve olumlu yönlerini kendi eğitim sistemlerine yeteri kadar uyarlamak da eğitim sistemlerinin gelişmesi açısından son derece önemlidir.

Eğitim dünyanın her yerinde, bir ulusun bütünlüğünü korumak, varlığını sürdürmek ve gelişimini sağlamak için olmazsa olmazlardandır. Dünya üzerinde farklı coğrafyalarda yaşayan kişilerin farklı farklı ihtiyaçları bulunmaktadır. Bu farklı ihtiyaçlar toplumların değerleri, normları, kültürel özellikleriyle ilgili olarak şekillenmektedir. Bu nedenle belirli bir toplumu eğitmek için o toplumun ihtiyaçlarına cevap verecek bir sistem geliştirmek gerekmektedir. Bunun yanı sıra, Dünya'daki eğitim uygulamalarına tamamen kapılarını bir ülkenin kapatması da uygun değildir. Dünyanın farklı yerlerindeki eğitim sistemlerini keşfetmek hiç şüphesiz o ülkeleri anlamanın, o ülkelerin gelişme veya geri kalma nedenlerini ortaya koymanın en önemli yolu olmaktadır. Bu sebeple çalışmada, öncelikle Kanada ve Bulgaristan, öğretmen yetiştirme, eğitim yönetimi ve denetimi sistemleri açıklanmış, ardından Türk Eğitim Sistemi ile karşılaştırılarak, benzer ve farklı yönlerini ortaya koymak amaçlanmıştır.

\section{Yöntem}

$\mathrm{Bu}$ bölümde araştırmanın modeli, ülkelerin seçilmesi, verilerin toplanması ve analizine ait bilgiler sunulmuştur.

\subsection{Araştırmanın Modeli}

Araştırmada Kanada, Bulgaristan ve Türkiye öğretmen yetiştirme, eğitim yönetimi ve denetimi sistemlerinin karşılaştırılması yapıldığı için, çalışma karşılaştırmalı bir eğitim çalışmasıdır. Araştırmada nitel araştırma yöntemi benimsenmiş olup; karşılaştırmalı tarama yöntemi kullanılmıştır. Bu konu ile ilgili öncelikle alan yazın taraması yapılmış, ülkelerin sistemleri arasındaki benzerlikler ve farklılıklar ortaya konulmuştur (Delibaş, 2007). Karşılaştırmalı çalışmalar, başka ülke 
veya ülkelerdeki var olan uygulamaları, durumları, çalışmaları, eğitimi incelemeyi amaçlayan bir alandır (Mugo ve Wolhuter, 2016). Bu çalışma tanımlayıcı karşılaştırmalı yaklaşımdır. Çünkü çalışılan konu ile ilgili alan yazın taraması, verilerin dokümanlardan toplanarak incelenmesi, benzer ve farklılıkların tespit edilerek karşılaştırmaların yapılmasını içermektedir (Türkoğlu, 1983; Ültanır, 2000). Aynı zamanda da yatay yaklaşım kullanılmıştır. Şöyle ki eğitim sistemlerinin tümü incelenmemiş sadece belli bölümleri araştırma kapsamına alınmıştır (Erbilgin ve Boz, 2013). Bu araştırmada ülkelerin eğitim sistemleri içerisinde yer alan öğretmen yetiştirme, eğitim yönetimi ve denetimi sistemleri karşılaştırılmıştır.

\section{2. Ülkelerin Seçilmesi}

Araştırma kapsamında Bulgaristan ve Kanada ülkeleri seçilmiştir. Ülkeler seçilirken amaçlı ölçüt örnekleme yöntemi kullanılmıştır. Ölçütler bir OECD üyesi (Kanada), bir OECD üyesi olmayan (Bulgaristan) ülke olması, iki ülkenin daha önce birlikte bir araştırmada karşılaştırılmamış olması, Kanada'nın PİSA 2015 sonuçlarına göre en başarılı ilk 10 ülke içerisinde yer alması, Bulgaristan'ın ise başarı düzeyinin Kanada'dan geri ama Türkiye'den daha ileri düzeyde olması sebebiyledir.

\subsection{Verilerin Toplanması ve Analizi}

Araştırma için veriler toplanırken çeşitli kaynakların kullanılmasına ve bunların güncel olmasına dikkat edilmiştir. Bu kaynaklar arasında bilimsel makaleler, kitaplar, ülkelerin eğitim bakanlıklarının web siteleri, UNESCO, Eurydice gibi uluslararası kabul edilen eğitim sitelerinden de yararlanılmıştır. Veriler toplandıktan sonra dokuman incelemesi yöntemi kullanılarak incelemeler ve karşılaştırmalar yapılmıştır. Doküman incelemesi, araştırılan olgu ve olgular ile ilgili bilgilerin yer aldığı yazılı olan tüm materyallerin analizini içermektedir. Doküman incelemesinde veri toplanırken, gözlem ve görüşme yapmaya gerek yoktur. Veriler, bu yöntemin beş karakteristik aşaması olan (1) dokümanlara ulaşma, (2) özgünlüğü kontrol etme, (3) dokümanları anlama, (4) veriyi analiz etme ve (5) veriyi kullanma (Yıldırım ve Şimşek, 2005) aşamaları takip edilerek analiz edilmiştir. Geçerlik ve güvenirliği sağlamak için; dokümanlardan elde edilen verilerin güncel olmasına dikkat edilmiştir. Veriler yorumlanırken, tablo haline getirilirken objektif olarak yaklaşılmış, kişisel görüş ve yorumlar çalışmaya yansıtılmamıştır.

\section{Bulgular}

Çalışmanın bu bölümünde önce Kanada, Bulgaristan ve Türkiye öğretmen yetiştirme, eğitim yönetimi ve denetimi sistemleri açılanmış, ardından benzer ve farklı yönleri ortaya konularak karşılaştırma yapılmıştır.

\section{1. Öğretmen Yetiştirme Sistemi}

Bu bölümde Kanada, Bulgaristan ve Türkiye öğretmen yetiştirme sistemleri incelenmiştir. 


\section{Kanada}

Kanada' da öğretmen olabilmek için iki farklı yol bulunmaktadır. Bunlardan biri "eş zamanl programlar" diğeri ise "sıral programlar" olarak adlandırılmaktadır. Eş zamanlı programlarda, akademik alana ait olan derslerle, diğer eğitim derslerini öğretmen adayları aynı anda almakta ve bu eğitim ya dört yıllık lisans eğitimi ile aynı zamanda tamamlanmakta ya da bir yıl yüksek lisans eğitiminde bu dersler verilmektedir. Sıralı programlarda ise öncelikle öğretmen adaylarının dört yıllık eğitimlerini tamamlamaları ve ardında da iki ile dört dönem arasında değissen öğretmenlik alan derslerinin verildiği programları tamamlamaları beklenmektedir. Eyaletler genellikle sıralı programları öğretmen eğitimi için tercih etmelerine rağmen Quebec hemen hemen tüm programlarını eş zamanlı olarak sürdürmektedir. Ülke genelinde öğretmenlerin yaklaşık yüzde yirmisinin yüksek lisans derecesi bulunmaktadır. İlkokuldaki öğretmenler genel uygulayıcılar kabul edilmesine rağmen ortaöğretimde çalışan öğretmenlerin en az iki dalda uzmanlaşmaları beklenmektedir. $\mathrm{Bu}$ nedenle ilköğretim öğretmeni yetiştiren programların çoğu eş zamanlı, ancak ortaöğretim öğretmeni yetiştirme programlarının ise sıralı programlar olduğu görülmektedir. Eyaletlerin çoğunda benzerlik gösteren bir başka uygulama ise öğretmenlerin öğrencilikleri ve stajyerlikleri boyunca yerinde uygulamalar yaparak eğitilmeleridir (CMEC; 2010 akt. Bakioğlu ve Pekince, 2018).

Ontario eyaletindeki öğretmen yetiştirme sistemine bakıldığında; öğretmen yetiştirmenin temel içeriğinde üç bölüm görülmektedir. Bunlar: 1) Öğretim programları bilgisi 2) Pedagojik ve öğretim stratejileri bilgisi 3) Öğretim içeriğinde bulunan temel alanlardır. Öğretim Programları; güncel öğrenme ve öğretme ile ilgili araştırmaları, Ontario'ya ait belirli öğretim programlarını ve planlamayı, özel eğitimi, eşitliği, çeşitliliği ve değerlendirmeyi kapsamaktadır. Pedegojik ve öğretim stratejileri; eğitim araştırmalarını, veri analizini, teknolojiyi eğitim aracı olarak kullanmayı, sorgulamaya dayalı araştırmayı, veri değerlendirmeyi, öğrencinin gözlemlenmesini, ölçümünü ve değerlendirilmesi ile ilgili yeni yaklaşımları, yeni öğretme stratejilerini, öğrenme ve öğretme kuramlarını, metotlarını, farklılaştırılmış öğretimi kapsamaktadır. Ayrıca pedagojik ve öğretim stratejileri sınıf yönetimini, örgütsel becerileri, çocuk ve ergen gelişimini de içine almaktadır. Öğretim içeriği; Ontario'daki okul çevresini kapsayan ruh sağlığı bilgisini, Ontario öğretmenler kolejinin öğretmenlik mesleği uygulaması için belirlediği standartları, öğretmenlik mesleği için gerekli etik şartları ve Ontario eğitim kanunu ve mevzuatını kapsamaktadır (Huges, Laffier, Mamol, Morrison ve Petrarca, 2015).

\section{Bulgaristan}

Bulgaristan'da öğretmen eğitiminden sorumlu üç tane kurum vardır. Bunlar; Öğretmen eğitimi yüksekokulları (okul öncesi ve ilkokul öğretmenleri için), üniversiteler (her düzeyde öğretmen yetiştirmek için), teknoloji ve ekonomi bölümleri ve belli alanlarda uzmanlaşmış (daha çok mesleki eğitim için öğretmen yetiştirmektedir) üniversitelerdir (Psifidou, 2010). Bulgaristan'da öğretmen yetiştiren kurumlara kabul edilebilmek için bir takım şartların öğretmen olmak isteyenler 
tarafından yerine getirilmesi gerekmektedir. Öncelikle liseden yüksek bir mezuniyet ortalamasına sahip olmak, sonrasında ise yeterlik sınavına (üniversiteye kabul sınavı/ Matriculation) girmek gerekmektedir. Ayrıca, anadil Bulgarca ve yabancı dil yeterlik sınavı (İngilizce, Almanca, Fransızca, İspanyolca, Rusça dillerinden birinde) girmeleri gerekmektedir (Angelova, Dacheva ve Vlakova, 2016 akt. Aykaç ve Şahin, 2018).

Bulgaristan'da öğretmen yetiştiren kurumlardaki eğitim süresi lisans diploması almak için 4 yıldır. Yüksek lisans için 5 yıl, doktora içinse 7 yıl eğitim alınması gerekmektedir. Yüksekokul mezunu olanlar ise iki ya da üç yıl eğitim gördükten sonra lisans mezunu olabilmektedirler (Angelova, Dacheva, ve Vlakova, 2016 akt. Aykaç ve Şahin, 2018). Öğretmen olabilmek iki şekilde gerçekleşmektedir. Bunlardan birincisi eşzamanlı olandır. Öğretmen adayı alanındaki dersleri fakülteden alırken (örneğin, matematik, tarih bölümünden dersler almak gibi), aynı zamanda eğitimle ilgili ilave derslerini eğitim fakültesinden almaktadır. Diğer bir modelde art arda modelidir. Burada önce belli bir alandan mezun olunur, ondan sonra ister hemen ister belli bir zaman sonra öğretmenlik yeterlik dersleri alınarak öğretmen olunabilir (Psifidou, 2010).

Her iki model de hem teorik hem de pratik dersler içermektedir. Bu dersler 60 saat pedagoji (eğitim teorileri ve öğretim bilgisi), 45 saat psikoloji (yetişkin psikolojisi ve çocuk psikolojisi), 60 saat öğretim bilgisi/ belirlenmiş bir konu ile ilgili öğretim yöntemleri, 15 saat uzmanlık alanına bağlı olarak seçimlik derslerden oluşmaktadır. Bu seçimlik dersler iki grupta toplanmaktadır. Bunlar; pedagoji, psikoloji ve yöntemle ilgili dersler ve öğretmenin uzmanlığına göre belirlenmiş derslerdir (Psifidou, 2010).

Bulgaristan'da öğretmen olabilmek için; 120 saat staj yapılması gerekmektedir. 30 ders saati, okuldaki derslerin gözlem ve analizi yapılır. Bu süreç yükseköğretimden bir hocanın danışmanlığında yürütülür. 45 ders saati "devam eden öğretmenlik stajı" adı verilen bir dönem bulunmaktadır. Bu dönemde öğretmen adayları okul ziyareti, derslerin gözlemlenmesi ve mezuniyet öncesi okul stajına hazırlık yapmaktadır. 75 ders saati ise "mezuniyet öncesi öğretmenlik stajı" dönemidir. Bu staj dönemi üniversiteden ve staj yaptığı okuldan bir öğretmenin danışmanlığında yürütülür (Psifidou, 2010).

Öğretmen adayları eğitimlerini tamamladıktan sonra hem zorunlu hem de seçmeli derslerden sınava tabi tutulmaktadır. Profesyonel yeterlik alabilmek için devletin düzenlediği pratik ve uygulamalı bir sınavdan geçerler. Sınav öğretmen adaylarının konuşma ve savunma yaptığı bir sınav türüdür. Bu sınav devlet sınav komisyonu önünde yapılmaktadır. Bu komisyonun üyeleri ise yükseköğretim kurumunun rektörü tarafından atanmaktadır. Bu komisyonda mezuniyet öncesi öğretmenlik stajında öğretmen adayına danışmanlık yapan öğretmen de bulunur. Öğretmen adayı üniversitede başarılı olduğu takdirde, öğretmenlik yeterlik sertifikası verilir (Psifidou, 2010). Bunların yanı sıra Bulgaristan'da öğretmen olarak çalışabilmek için, kasıtlı olarak işlenmiş bir suçtan mahkûm olmamak, öğretmenlik mesleğini uygulama hakkından mahrum olmamak gerekmektedir. Bulgaristan'da öğretmen olmak için Bulgar vatandaşı olmaya gerek yoktur (Pravitami, 2018). 
Bulgaristan'da hizmet içi eğitimler yoluyla kariyer basamaklarında yatay ve dikey ilerlemek mümkündür. Yatay kariyer basamakları; stajyer öğretmen (Bu en az iki yıl sürmektedir.), öğretmen, baş (kıdemli) öğretmen, uzman öğretmen ve metodoloji öğretmeni şeklindedir. Dikey kariyer fırsatları ise, çoğunlukla yönetim kademelerinde yer almak anlamına gelmektedir. Öğretmenler okul müdürü, müdür yardımcısı, bölgesel eğitim müfettişleri, Eğitim ve Bilim Bakanlığında yönetici gibi kademelere gelebilmektedir (Psifidou, 2010).

\section{Türkiye}

Türk eğitim sisteminde öğretmenlik mesleğiyle ilgili 1739 sayılı Milli Eğitim Temel Kanunun 43. maddesine göre; öğretmenlik mesleğinin bir uzmanlık mesleği olduğu, ayrıca öğretmenlerin yüksek öğretim mezunu olması gerektiği, genel kültür, özel alan bilgisi ve pedagojik formasyon alarak öğretmenlik yapabilecekleri belirtilmiştir. Türkiye'de şu anda hem eğitim fakültelerinden doğrudan öğretmen olarak mezun olmak, hem de diğer fakültelerden mezun olup pedagojik formasyon alarak öğretmen olmak mümkündür. Bunun yanı sıra yine aynı kanunun 45 . maddesinde öğretmenlerin Milli Eğitim Bakanlığı [MEB] tarafından seçileceği kanunda yer almıştır. Ayrıca MEB Talim ve Terbiye Kurulu Başkanlığı tarafından hazırlanan "Öğretmenlik Alanları, Atama ve Ders Okutma Esasları"nın 7. maddesine göre "öğretmen olarak atanacaklarm gerekli ve yeterli düzeyde genel kültür, özel alan eğitimi ve pedagojik formasyon almaları esastır" diye belirtilmektedir (Tebliğler Dergisi, 2018).

Türkiye'de günümüzde öğretmen yetiştirme iki farklı yolla gerçekleşmektedir. Bunlardan ilki eğitim fakültelerinde öğretmen yetiştirme; ikincisi ise yükseköğretim lisans programlarından mezun olanlara "Pedagojik Formasyon Eğitimi" verilerek öğretmen yetiştirmedir. Türkiye' de öğretmen yetiştiren programlara öğrenci seçiminde öğrenciler hizmet öncesi eğitim programlarına, öğretmen gereksinimi gözetilmeden, genel ölçütlere göre seçilmektedir. Hizmet öncesi eğitimin sonunda ikinci bir eleme yapılarak öğretmen gereksinimine göre atama yapılmaktadır (Türkiye'de Öğretmen Eğitimi ve İstihdamı, 2017). Kısaca, üniversite sınavına giren öğrenciler eğitim fakültelerine yerleştirilmekte, okurken pedagojik formasyonla ilgili derslerini almakta ya da fakülte mezunu olup pedagojik formasyon almakta ve mezun olduktan sonra devlet kadrolarına atanmak için tekrar KPSS sınavına girmektedirler (İdin, 2012).

2006-2007 akademik yılından itibaren uygulanmaya başlanan öğretmen yetiştirme programına göre programlar; yaklaşık \%50 alan bilgisi, \%30 öğretmenlik meslek bilgisi ve \%20 genel kültür derslerini içermektedir. Bu yüzdeler öğretmenlik dallarına göre farklılık göstermektedir. Oysa Pedagojik Formasyon Eğitimi Sertifika Programinda sadece meslek bilgisi dersleri yer almaktadır. Kısa dönemli Pedagojik Formasyon Eğitimi Sertifika Programında meslek bilgisi derslerinin yer aldığı (toplam 34 saat), ancak alana özgü meslek bilgisine yönelik derslerin bulunmadiğı görülmektedir. Diğer yandan Eğitim Fakültesi Ö̆gretmen Eğitimi Programlarının tamamında hem meslek bilgisi derslerinin hem de alana özgü meslek bilgisi derslerinin olduğu gözlenmektedir. Bu derslerin toplam saati alanlara göre değişmektedir. Dolayısıyla Pedagojik Formasyon Eğitimi alan adaylar, Eğitim Fakültesi adaylarının 
yaklaşık yarısı kadar eksik mesleki bilgiye sahip olmaktadır (Türkiye'de Öğretmen Eğitimi ve İstihdamı, 2017).

Türkiye'de öğretmen yetiştirme işi YÖK'ün sorumluluğu ve denetimi altındadır. MEB ile üniversitelerin eğitim fakülteleri arasında yapılan işbirliği ile hizmet öncesi öğretmenlerinin bakanlığa bağlı eğitim kurumlarında staj görmeleri söz konusudur. Hizmet öncesi öğretmenleri "Okul Deneyimi" ve "Öğretmenlik Uygulaması" dersleri ile eğitim kurumlarında staj yapmaktadırlar (İdin, 2012).

\section{2. Ĕ̆itim Yönetimi}

Bu bölümde Kanada, Bulgaristan ve Türkiye eğitim yönetimi sistemleri incelenmiştir.

\section{Kanada}

Kanada'da 1967'de ortaya konan Kuruluş Sözleşmesi ile (Constitutional Act) eğitim ile ilgili yetkiler eyaletlere verilmiştir (Council of Ministers of Education Canada -CMEC, 2008). Kanada OECD ülkeleri arasında ulusal eğitim bakanlığ bulunmayan tek ülkedir. Kanada'da bulunan her bir eyalet kendi eğitim sisteminden sorumludur (Morgan, 2011). Kanada 'da federal bir devlet, eyaletler ve yerel yönetimler şeklinde bir devlet yapılanması bulunmaktadır. Bu yapılanma etrafında eğitim gerçekleştirilmektedir. Federal hükümetin eğitime direk bir etkisi bulunmamaktadır. Federal yönetim genel eğitim politikalarının oluşturulmasında, eğitim standartlarının belirlenmesinde ve eğitimin finansmanında etkili olmaktadır. Kanada'da eğitimle ilgili yasalar her eyaletin kendi bünyesinde çıkarılmaktadır (UNESCO, 2006). Kanada'da 10 eyalet ve 3 bölgenin her birinde bulunan eğitim daireleri ya da eğitim bakanlıklarl; eğitim örgütlenmesinin nasıl olacağından, eğitimin nasıl verileceğinden, yasa ve yönetmeliklerin ne şekilde olacağından, ayrıca ilköğretim, ortaöğretim, teknik eğitim, mesleki eğitim ve ortaöğretim sonrası eğitim de ölçme ve değerlendirmenin nasıl yapılacağından ve okul kurullarının nasıl oluşturulacağından, okul programlarının nasıl yapılacağından sorumludur. Bazı eyaletlerde ya da bölgelerde bu işlemler için iki ayrı bakanlık veya daire bulunmaktadır. Bunlardan bir tanesi ilköğretim ve ortaöğretimden sorumlu iken diğeri ortaöğretim sonrası eğitim ve ustalık eğitiminden sorumludur (Council of Ministers of Education Canada -CMEC, 2008).

Okullarda bulunan okul yönetim kurulları eyaletlerden aldıkları yetki ile tüm okulla ilgili programların hazırlanmasından sorumludur. Okul kurullarının görevleri şunlardır: Okul bütçesini hazırlamak, okul genelinde katkı paylarını belirlemek, ilk, orta ve teknik okulların planlamasını yapmak, öğretmen ve denetçilerin sözleşmelerini yapmak, gerekli bölgelere yeni okul inşaatları yapmak, eyaletlerin eğitim politikaları ile okul politikaları arasındaki uyumu sağlamaktır. Ayrıca Kanada eğitim politikaları doğrultusunda alınan kararlara uygunluğu denetlemek için Kanada Eğitim Bakanlığ1 Konseyi oluşturulmuştur. Bu konseyin görevleri arasında, uluslararası alanda Kanada'yı temsil etmek, federal yönetimle işbirliği yapmak, bölgeler ve eyaletler 
arasında danışma ve işbirliği sağlamak ve karşılıklı olarak ilişkileri düzenlemek yer almaktadır (Encyclopedia of Education, 1971; Ültanır, 2000 akt. Taşdan, 2009).

Büyük okul bölgelerinde ve belediyelerde yönetici seçimleri genellikle yerel eğitim yöneticileri ya da ona eşdeğer pozisyondaki kişiler tarafından gerçekleştirilmektedir. Ancak tek yetkili kişiler onlar değildir. Bu seçimler genellikle bir komite ya da kurul tarafından gerçekleştirilmektedir. Örneğin, Kanada'daki Ontario eyaletinde müdürlerin ve müdür yardımcılarının en son final seçimleri eğitim yöneticisi, eğitim yöneticisinin yardımcısı, bunun yanı sıra kıdemli denetmelerden oluşan bir grubun işbirliği içerisinde gerçekleştirilmiştir. Seçimler okulun yönetim kurulu (okul mütevelli heyeti) tarafından onaylanmak zorundadır. Okul bölgesi (district) karar verme sürecinde en önemli role sahiptir. Ancak, bu süreç aynı zamanda Eğitim Bakanlığı ve Müdürler Birliği'nin de dâhil olduğu bir süreçtir. Her ikisi de kendine has şekilde ve kendi bildiği yolla bu seçime katılmaktadır. Yönetici seçimiyle ilgili bir örnek vermek gerekirse, Ottawa Katolik Okulu yöneticilerin işe alımıyla ilgili esasları belirleyerek; boş olan kadrolara yönetici seçiminde okul kurulu (okul mütevelli heyeti), eğitim direktörü, denetmenler ve müdürden oluşan bir heyetle seçim yapılacağını bildirmektedir (Taipale, 2012).

Kanada'da öğretmenlerin yönetici olabilmek için özel bazı yeterliliklere sahip olmaları gerekmektedir. Yönetici olabilmek için ya yüksek lisans yapmaları ya da iki bölümden oluşan yönetici yeterlikleri programını tamamlamaları gerekmektedir. Özel okullar için bu ölçütler geçerli değildir. Onlar kendi yöneticilerini kendi belirledikleri ölçütlere göre seçmektedir. Ayrıca, bu yeterlilikler eyaletler arası farklılıklarda göstermektedir ve yöneticiler yerel kurallar nedeniyle yeniden yöneticilik lisansı almak zorunda kalabilmektedir (Taipale, 2012). Örneğin, Ontario'da Ontario Eğitim yasasının 184/97 sayılı yönetmeliğine göre Ontario Eğitim Fakültesi'nden akreditasyon almak isteyen bir öğretmen öncelikle geçerli bir lisans diplomasına sahip olmalıdır. Ayrıca beş yıl en az öğretmenlik yapmış olması ve en az iki dalda uzmanlaşmış olması veya yüksek lisans derecesine sahip olması gerekmektedir. Bunlara sahip olan öğretmen Okul Müdürleri Yeterlik Kazandırma Programı'nı (PQP) tamamlayarak bu belgeyi almaya hak kazanmış olur. Bu program Ontario Öğretmenler Federasyonu ve Ontario Müdürler Kurulu'nun birlikte yürüttükleri ve Ontario Eğitim Fakültesinde gerçekleştirilmektedir. Bu programda 125 saatlik ve iki bölümden oluşan dersler verilmekte ayrıca, liderlik, mentörlük, staj gibi birtakım aktif katılım gerektiren uygulamalar da bulunmaktadır. Bu eğitim ücretlidir ve finansman programa katılan öğretmenler tarafından karşılanmaktadır (Normore, 2004; OECD, 2010; Walker, Bryant ve Lee, 2003 akt. Gümüş ve Bellibaş, 2015).

\section{Bulgaristan}

Bulgaristan'da okul öncesi ve okul dönemi; anaokullarını, diğer okulları, kişisel gelişim ve destek merkezlerini, özel hizmet birimlerini kapsamaktadır. Bütün bu okul türleri devlet tarafından belirlenmiş standartlara göre eğitim hizmeti vermektedir. Devletin eğitim standartları genel ve mesleki eğitimin ne düzeyde yapılacağını belirlemektedir. Bu standartlar eğitimin içeriği, ders kitapları, okullara yapılacak 
yardımlar, öğretmenlik yeterlik sertifikaları, öğretmen yeterlilikleri, ölçme değerlendirme sistemi, eğitim denetiminin eğitim ortamlarında ne şekilde yapılacağı ile ilgili bilgileri kapsamaktadır (Eurydice, 2018).

Bulgaristan'daki okullarda iki temel yapı bulunmaktadır. Bunlardan bir tanesi okul müdürü ve müdür yardımcıları diğer ise pedagojik konseydir. Ayrıca Bulgaristan'daki pek çok okulda velilerin katılımını arttırmak için okul mütevelli heyetleri de oluşturulmaktadır. Bulgaristan'da okul öncesi, temel eğitim ve ortaöğretim hem belediyeler hem de devlet tarafından yürütülmektedir. Belediyeler okulların büyük bir bölümüne sahiptir. Bulgaristan'da az sayıda özel okul ve özel üniversite yer almaktadır (Parvanova, 2013).

Okulların yönetimindeki en önemli unsur okul müdürüdür. Okul müdürü olabilmek için pek çok kriterin var olması gerekmektedir. Okul müdürü olabilmek için en az üç yıl öğretmenlik deneyimi, yüksek lisans derecesi, herhangi bir suça karışmamış, herhangi bir sebepten görevden atılmamış ya da uzaklaştırılmamış olmak gerekmektedir. Kişinin öğretmenliğe uygun yeterliğe sahip olması ve Kamu Eğitim Yasası'nda belirtilen miktarda ders verebilmesi gerekmektedir. Son yıllarda, okul müdürlerini işe alım sürecinde bu belirtilenlere ilave bazı yeni şartlar da getirilmiştir. Örneğin, Eğitim ve Bilim Bakanlığ Ulusal Enstitüde müdürler özel bir okul yönetimi kursuna tabi tutulmaktadırlar. Bu henüz yasal bir zorunluluk olmasa da, müdür adaylığ kredi kazandırmaktadır. Okul müdürlerinin seçimi ve atanması sırasında hem adaylarla mülakat yapılmakta hem de okul gelişimi ile ilgili kavramların tanıtılması beklenmektedir (Parvanova, 2013).

Devlet okullarına müdür seçimleri Eğitim ve Bilim Bakanlığı tarafından Bölgesel Eğitim Müfettişliğinden atanan bir komisyon tarafından gerçekleştirilir. Belediyeye ait okullara müdür seçimlerinde ise Bölgesel Eğitim Müfettişlerinin başkanı tarafından atanan eğitim müfettişlerinin yanı sıra belediye başkanı tarafından atanan belediye yönetiminden de üyeler bulunmaktadır (Parvanova, 2013). Son yıllarda merkezileşmeden uzaklaşmaya başlamakla birlikte okul müdürleri idareciden çok, yönetici olarak kabul edilmektedirler. Okul müdürlerinin yetkileri ve sorumlulukları giderek artmaktadır. Okul müdürleri, okulun tüm işlevlerinden ve çevresinden sorumludur. Ayrıca, eğitim için olan ulusal standartların okul içerisinde uygulanmasından ve kontrolünden sorumludur. Bunun yanı sıra, öğretmenlerin, müdür yardımcılarının, okulda görevli personelin seçimi ve atanmasından, planlamadan, okul bütçesinin en tasarruflu şekilde idare edilmesinden, görev tanımlamalarından, iş organizasyonunun yapılması, yasa gereği maaşların hazırlanması, okul kuralları ve ulusal yasalar dikkate alınarak öğrencilere ceza verilmesi, öğretmenlerin ve diğer personelin işten çıkarılması, öğrenci kayıtlarının planlanması, çeşitli organizasyonlarda ve otoriteler önünde okulun temsil edilmesi, belgelerin kontrolü ve saklanmasından, okul çalışma planının yapılmasından, öğretmenlerin sinıflara atanmasından sorumludur (Parvanova, 2013). 


\section{Türkiye}

Türkiye'de okullar devlet eliyle MEB tarafından tek bir elden yönetilmektedir. Öğretmenlerin, yöneticilerin, maarif müfettişlerinin seçimi ve görevlendirilmesi devlet eliyle yürütülmektedir (Milli Eğitim Temel Kanunu, 1973). Okul yöneticisi olabilmek için fakülte mezunu olmak, bakanlık kadrolarında öğretmen olarak görev yapıyor olmak, görevlendirileceği eğitim kurumunda okutacağı dersi bulunmak ve yine yönetici olarak atanacağı türdeki eğitim kurumlarından birine öğretmen olarak atanabilecek niteliklere sahip olmak, yazılı sınavın yapılacağı son gün itibarı ile adli ve idari soruşturma sonucu görevinden alınmış olmamak, zorunlu çalışma yükümlüsü olan yerler dışındaki yönetici kadrolarına atanmak için zorunlu çalışma yükümlüsü olmamak genel özellikler olarak belirtilmiştir. Ayrıca müdür olabilmek için; müdür olarak görev yapmış olmak, kurucu müdür, müdür başyardımcısı, müdür yetkili öğretmen olarak ayrı ayrı ya da toplamda en az bir yıl bu görevleri yapmış olmak, ya da şube müdürü ya da daha üst kadrolarda görev yapmış olmak gerekmektedir. Bu sıralanan şartlardan en az birini taşımaları müdürlük için ön şarttır. Müdür yardımcısı olabilmek için de bir takım özel şartlar gerekmektedir ve yine bu şartlardan en az birini müdür yardımcısı olacak kişilerin taşıması gerekmektedir. Bu şartlar şu şekilde sıralanmıştır; müdür, kurucu müdür, müdür başyardımcısı, müdür yardımcısı veya müdür yetkili öğretmen olarak görev yapmış olmak. Bakanlığın şube müdürü veya daha üst unvanlı kadrolarında görev yapmış olmak ya da adaylık dâhil en az iki yıl öğretmen olarak görev yapmış olmaktır (MEB Eğitim Kurumlarına Yönetici Görevlendirme Yönetmeliği, 2018).

\subsection{Eğitim Denetimi}

Bu bölümde Kanada, Bulgaristan ve Türkiye eğitim denetimi sistemleri incelenmiştir.

\section{Kanada}

Kanada eğitim sistemi bölgeler düzeyinde yürütülmektedir. Her bölgenin kendine ait eğitim bakanlığı bulunmaktadır. Federal devlet eğitim politikalarını oluşturmakta ve finansal anlamda yerel hükümetlere destek vermektedir. Üniversitelerle ilgili hususlarda bile bölgeler kendi sistemlerini ve kendi akreditasyon sistemlerini uygulamaktadır (Kirby, 2007). Okullar hakkındaki beklentiler ve okullara kamu tarafından yapılan kaynak temini, eğitim bölgelerinde öğrencilerle ilgili olan eğitim çıtılarının elde edilmesinde harcanan çabanın ne kadar olduğu konusundaki merakı Kanada'da giderek arttırmaktadır (Klinger, Shulha ve Deluca, 2008). Okullar sürekli olarak öğrencilerin gelişmesi ve büyümesi ile ilgili çabalar durumdadır. Bu amaçla ülke genelinde öğrencilere uygulanan PISA, TIMMS, PRILS, Pan- Kanada Test Programı (PCAP) gibi bir takım sinavlar bulunmaktadır. Bu sınavlar özellikle son yıllarda çok önem kazanmış ve sınavlardan elde edilen sonuçlara göre okullar değerlendirilmeye başlanmıştır. Ayrıca bu sınav sonuçları sadece öğrencileri değerlendirmek için değil, bunun yanı sıra mevcut uygulamaların öğretmen profesyonelliğine yansımalarını değerlendirmek, mesleki gelişmeler hakkında öğretmenleri bilgilendirmek, sistem genelinde yenilemeler yapmak ve Kanada eğitim 
sistemini hem ulusal hem de uluslararası düzeyde değerlendirmek için de kullanılmaktadır (Copp, 2015).

Kanada'da sınıf denetimi, öğretmen denetimi ve öğretmen rehberliği okul müdürleri kanalıyla yürütülmektedir. Okul müdürleri öğretmenlerin derslerine birkaç kez girerek sınıf gözlemlerinde bulunmaktadır. Ayrıca okul kurulları (school boards) bölgelerinde bulunan okullardaki öğretmenleri değerlendirmektedir. Bunun yanı sıra öğretmenler bulundukları illerdeki il eğitim bakanlıklarının veya il düzenleme kurullarının koydukları davranış kurallarına uymak zorundadır (Klinger Shulha ve Deluca, 2008).

\section{Bulgaristan}

Bulgaristan Eğitim ve Bilim Bakanlığı bünyesinde müfettişlik birimi bulunmaktadır. Bu birimde bulunanlar bakanlığın kontrol işleriyle ilgilenmektedirler. Bölgesel müfettişlik birimleri ve bu birimlerde görevli müfettişlerle eğitim denetimi yürütülmektedir. Müfettişlik birimleri Eğitim ve Bilim Bakanlığı adına araştırmaları ve denetimleri gerçekleştirmekte ve bakana sunulmak üzere raporları hazırlamaktadır. Bakanlık Müfettişleri Bölgesel birimleri idari açıdan denetlemektedir. Ayrıca yıllık faaliyetleri konusunda bakanlığa rapor sunmaktadırlar (Chairoula, 2011).

Bakanlık Müfettişleri ve Bölge Müfettişleri okul müdürleri arasından sınavla seçilirler. Her yerel kademede her belediye bünyesinde bir eğitim müfettişi bulunur (Chairoula, 2011). Müfettişlerin görevleri şunlardır: Yönetimin etkililiğini analiz etmek, yönetimde iş organizasyonunun iç düzenlemelere uygunluğunu denetlemek, kamu görevlilerinin görevlerini kötüye kullandıkları durumlarda, disiplin soruşturması başlatılmasını teklif etmektir. Çalışanların kuralları ihmallerini, yasadışı faaliyetlerini şikâyet etmek ve isteklerini kontrol etmektedir. Bozulmaya karşı mücadele etmek ve çıkar çatışmalarını önlemektir. İstihdamın kamu hizmet kanunu açısından uygunluğunu denetlemektir. Çatışmaları önlemek ve tespit etmek ile ilgili yasaya uygunluğu kontrol etmektir. Yetkili makamlar tarafından belirlenen diğer idari denetimle ilgili faaliyetleri yürütmektir (Chairoula, 2011).

Bölgesel düzeyde, eğitim sisteminin değerlendirilmesi Eğitim Bölge Müfettişliği uzmanları tarafından yapılmaktadır. Bu uzmanlar okul çalışmalarını bir bütün olarak değerlendirmekte, danışmanlık hizmeti vermekte, müdürlerin çalışmalarını yönetmekte, öğretmenlerin eğitim performansını denetlemekte, öğrencilerin öğrenme düzeylerini gözlemlemektedir. Ortaöğretim değerlendirilmesi için Eğitim Kalitesini Kontrol ve Değerlendirme Merkezi kurulmuştur (The Center for Control and Evaluation of the Quality of Education). Bu merkez tüm derslerde test hazırlamaktan, bu testin okullarda uygulanması, toplanan verilerin değerlendirilmesi, teknik ve yüksekokulların değerlendirilmesinden sorumludur. Yükseköğretimde değerlendirme, uzman bir devlet birimi tarafından gerçekleştirilir (Ulusal Değerlendirme ve Akreditasyon Ajansı). Bu ajansın temel amacı eğitimin kalitesini değerlendirmek ve yüksekokullardaki eğitimin Yükseköğretim Yasasıyla uyumlu olmasını sağlamaktır (Chairoula, 2011). 


\section{Türkiye}

Türkiye'de eğitim denetim sistemine bakıldığında ise 14.03 .2014 tarihli 6528 sayılı Millı̂ Eğitim Temel Kanunu İle Bazı Kanun ve Kanun Hükmünde Kararnamelerde Değişiklik Yapılmasına Dair Kanun ile yapılan değişiklikler sonucunda Millî Eğitim Denetçiliği ve İl Eğitim Denetmenliği unvanları Maarif Müfettişi unvanıyla birleştirilmiş ve Rehberlik ve Denetim Başkanlığında görev yapan Millî Eğitim Denetçileri İl Millî Eğitim Müdürlükleri bünyesinde oluşturulan Maarif Müfettişleri Başkanlıklarına atanmıştır. 652 sayılı MEB Teşkilat ve Görevleri Hakkında Kanun Hükmünde Kararname ile Rehberlik ve Denetim Başkanlığına verilen görevlerin yerine getirilmesi amaciyla Başkanlıkta Maarif Müfettişleri görevlendirilmesi yapılmıştır (Teftiş Kurulu Başkanlığ1, 2018). En son 2014 ve 2016'da yapılan düzenlemenin ardından yeni tanımlanan maarif müfettişlerinin görevleri arasında öğretmen denetimi yer almamaktadır. Dolayısıyla, öğretmenlerin ders denetimi işleri daha önce belirlenen mevzuat gereğince okul müdürlerine bırakılmıştır (Ergen ve Eşiyok, 2017).

Maarif müfettişleri MEB tarafından okul ve bakanlık kurumlarına, özel öğretim kurumlarına, gerçek ve tüzel kişilere rehberlik etmektedir. Maarif müfettişleri bakanlıkta veya bakanlık kontrolünde olan kurumların, denetimine sunulan hizmetlerin kontrol ve denetimini ilgili birimlerle işbirliği içinde yapmaktadır. Süreç ve sonuçların mevzuata, önceden belirlenmiş amaç ve hedeflere, performans ölçütlerine ve kalite standartlarına göre analiz etmek, karşılaştırmak ve ölçmek, kanıtlara dayalı olarak değerlendirmek, elde edilen sonuçları rapor hâline getirerek ilgili birimlere ve kişilere iletmek görevleri yine maarif müfettişlerine aittir. Ayrıca, MEB teşkilatı ile bakanlığın denetimi altındaki her türlü kuruluşun faaliyet ve işlemlerine ilişkin olarak, usulsüzlükleri önleyici, eğitici ve rehberlik yaklaşımını ön plana çıkaran bir anlayışla, bakanlığın görev ve yetkileri çerçevesinde denetim, inceleme ve soruşturmalar yapmak da maarif müfettişlerinin görevidir (MEB Teşkilat ve Görevleri Hakkında Kanun Hükmünde Kararname, 2011). MEB Rehberlik ve Denetim Başkanlığı ile Maarif Müfettişleri Başkanlıkları Yönetmeliği (2014) ile okullardaki öğretmen-ders denetimi, müfettiş ve müfettiş yardımclarının görev ve yetkileri arasından çıkarılarak, okul müdürlerine verilmiştir. Müfettişler sadece kurum teftişi yapmakla görevlendirilmiştir.

Çalışmada Kanada, Bulgaristan ve Türkiye öğretmen yetiştirme, eğitim yönetimi ve denetimi sistemleri incelenmiştir. Yukarıda anlatılanlar doğrultusunda ülkeler arasında bir takım benzerlik ve farklılıkların olduğu görülmüştür. Bu ülkelere ait incelenen bilgiler Tablo 1'de özetlenmiştir. 
Tablo 1. Kanada, Bulgaristan ve Türkiye Öğretmen Yetiştirme, Eğitim Yönetimi ve Denetimi Sistemlerinin Karşılaştırılması

\begin{tabular}{|c|c|c|c|}
\hline Kriter & Kanada & Bulgaristan & Türkiye \\
\hline 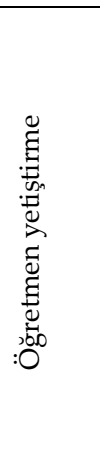 & $\begin{array}{l}\text { Öğretmen yetiştirmede } 2 \text { yol vardır. "eş zamanlı } \\
\text { programlar" diğeri ise "sıralı programlar"dır. } \\
\text { 1.Eş zamanlı programlar: Akademik alanına ait olan } \\
\text { derslerle diğer eğitim dersleri öğretmen adaylarınca aynı } \\
\text { anda alınmakta, bu eğitim ya dört yıllık lisans eğitimi ile } \\
\text { aynı zamanda ya da bir yıl yüksek lisans eğitiminde } \\
\text { alınmaktadır. } \\
\text { 2.Sıralı programlar: Öğretmen adaylarının dört yıllık } \\
\text { eğitimlerinin ardından iki ile dört dönem arasında } \\
\text { öğretmenlik alan derslerinin verildiği programları } \\
\text { tamamlamaları beklenmektedir (CMEC; } 2010 \text { akt. Bakioğlu } \\
\text { ve Pekince, 2018). }\end{array}$ & $\begin{array}{l}\text { Öğretmen eğitiminden sorumlu } 3 \text { yol vardır. } \\
\text { 1.Öğretmen eğitimi yüksekokulları (okul öncesi ve } \\
\text { ilkokul öğretmenleri için), } \\
\text { 2.Üniversiteler (her düzeyde öğretmen yetiştirmek } \\
\text { için), } \\
\text { 3.Teknoloji ve ekonomi bölümleri ve belli alanlarda } \\
\text { uzmanlaşmış (daha çok mesleki eğitim için öğretmen } \\
\text { yetiştirmektedir) üniversitelerdir (Psifidou, 2010). }\end{array}$ & $\begin{array}{l}\text { Türkiye'de günümüzde öğretmen yetiştirme } 2 \text { farklı yolla } \\
\text { gerçekleşmektedir. } \\
\text { 1.Eğitim fakültelerinde (İlahiyat ve BESYO'larda da } \\
\text { öğretmenlik programı mevcuttur) öğretmen yetiştirme; } \\
\text { 2.Yükseköğretim lisans programlarından mezun olanlara } \\
\text { Pedagojik Formasyon Eğitimi verilerek öğretmen } \\
\text { yetiştirmedir (Türkiye'de Öğretmen Eğitimi ve İstihdamı, } \\
\text { 2017). }\end{array}$ \\
\hline 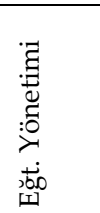 & $\begin{array}{l}\text { Eğitim yönetimi bölgesel olup; her eyaletin ayrı bir eğitim } \\
\text { bakanlığı vardır (UNESCO, 2006). }\end{array}$ & $\begin{array}{l}\text { Eğitim yönetimi merkezden olup; Eğitim ve Bilim } \\
\text { Bakanlığı vardır (Eurydice, 2018). }\end{array}$ & $\begin{array}{l}\text { Eğitim yönetimi merkezden olup; Milli Eğitim Bakanlığı } \\
\text { vardır (MEB Teşkilat ve Görevleri Hakkında KHK, 2011). }\end{array}$ \\
\hline 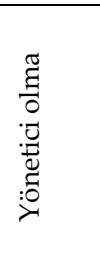 & $\begin{array}{l}\text { Öğretmenlerin yönetici olabilmek için ya yüksek lisans } \\
\text { yapmaları ya da iki bölümden oluşan yönetici yeterlikleri } \\
\text { programını tamamlamaları gerekmektedir. Ayrıca, bu } \\
\text { yeterlilikler eyaletler arası farkll1ıklarda göstermektedir ve } \\
\text { yöneticiler yerel kurallar nedeniyle yeniden yöneticilik } \\
\text { lisansı almak zorunda kalabilmektedir (Taipale, 2012). }\end{array}$ & $\begin{array}{l}\text { Okul yöneticisi olabilmek için pek çok kriterin var } \\
\text { olması gerekmektedir. En az üç yıl öğretmenlik } \\
\text { deneyimi, yüksek lisans derecesi, herhangi bir suça } \\
\text { karışmamış, herhangi bir sebepten görevden } \\
\text { atılmamış ya da uzaklaştırılmamıs olmak } \\
\text { gerekmektedir (Parvanova, 2013). }\end{array}$ & $\begin{array}{l}\text { Okul yöneticisi olabilmek için fakülte mezunu olmak, } \\
\text { bakanlık kadrolarında öğretmen olarak görev yapıyor } \\
\text { olmak, görevlendirileceği eğitim kurumunda okutacağı dersi } \\
\text { bulunmak, yazılı sınavın yapılacağı son gün itibarı ile adli } \\
\text { ve idari soruşturma sonucu görevinden alınmış olmamak } \\
\text { sayılabilir (MEB Eğitim Kurumlarına Yönetici } \\
\text { Görevlendirme Yönetmeliği, 2018). }\end{array}$ \\
\hline 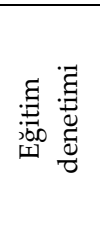 & $\begin{array}{l}\text { Öğretmenler bulundukları illerdeki il eğitim bakanlıklarının } \\
\text { veya il düzenleme kurullarının koydukları davranıs } \\
\text { kurallarına uymak zorundadır ve belirli zamanlarda kontrol } \\
\text { edilirler. Kanada'da sınıf denetimi, öğretmen denetimi ve } \\
\text { öğretmen rehberliği okul müdürleri kanalıyla } \\
\text { yürütülmektedir (Klinger vd., 2008). }\end{array}$ & $\begin{array}{l}\text { Eğitim ve Bilim Bakanlığı bünyesinde müfettişlik } \\
\text { birimi bulunmaktadır. Bölgesel müfettişlik birimleri ve } \\
\text { bu birimlerde görevli müfettişlerle eğitim denetimi } \\
\text { yürütülmektedir (Chairoula, 2011). }\end{array}$ & $\begin{array}{l}\text { Öğretmenlerin sınıf denetimi okul yöneticilerince } \\
\text { yapılmaktadır (Ergen ve Eşiyok, 2017). }\end{array}$ \\
\hline
\end{tabular}


Tablo 1 incelendiğinde her üç ülkede de eğitimden sorumlu bakanlık biriminin olduğu görülmektedir. Türkiye ve Bulgaristan'da merkezi yönetim hakimken, Kanada'da her bölgenin bakanlığı ayrıdır. Yönetici olmak için hem Kanada hem de Bulgaristan'da yüksek lisans şartı varken; Türkiye'de böyle bir şart olmadığı görülmektedir. Eğitim denetimi sistemi incelendiğinde ise Kanada ve Türkiye'de sınıf denetimleri okul yönetici tarafından yapılırken; Bulgaristan'da müfettişler tarafından yapıldı̆̆ tespit edilmiştir.

\section{Tartışma, Sonuç ve Öneriler}

Yapılan çalışmada Kanada, Bulgaristan ve Türkiye öğretmen yetiştirme, eğitim yönetimi ve denetimi sistemlerin karşılaştırılması amaçlanmıştır. Bu amaçtan yola çıkarak benzerlikler ve farklılıklar ortaya konulmuştur. Kanada, Bulgaristan ve Türkiye öğretmen yetiştirme sistemi açısından birbirine benzeyen ve ayrışan yönlere sahiptir. Öğretmenlik eğitimi Kanada, Türkiye ve Bulgaristan'da iki şekilde yapılmaktadır. Bunların birincisinde, öğretmen adayları fakültelerde okurken öğretmenlik mesleği ile ilgili dersleri eş zamanlı alabilmektedir. İkinci yöntemde ise her üç ülkede de bir fakülteyi bitirdikten sonra pedagojik formasyon dersleri sonradan da alınabilmektedir. Bunun yanı sıra, her üç ülkede de öğretmenlik için eğitim kurumlarında staj yapma zorunluluğu bulunmaktadır. Üç ülkede de öğretmenlikle ilgili dersler ve staj üniversiteler tarafından yürütülmektedir. Hem Bulgaristan'da hem de Türkiye' de üniversite giriş sınavı bulunmaktadır. Ancak Kanada'da üniversiteye giriş için bir sınav mevcut değildir üniversiteye girmek için en önemli ölçüt lisede alınan dersler ve bu derslerin notlarıdır (Günay ve Gür, 2009). Bulgaristan'da ve Türkiye'de öğretmen olarak atanabilmek için devletin düzenlediği bir sınava girilmesi gerekmektedir. Kanada'da böyle bir sınav bulunmamaktadır. Bulgaristan'da okul öncesi ve ilkokul öğretmenleri yüksekokul mezunu olabilirler oysa Kanada ve Türkiye'de fakülte mezunu olmaları gerekmektedir (Günay ve Gür, 2009).

Kanada ve Bulgaristan'da devlet daha üst eğitim politikalarından eğitime kaynak sağlanmasından genellikle sorumlu bulunmaktadır. Okulların yönetilmesi eyaletler ve yerel yönetimler tarafından yapılmaktadır. Bunun yanı sıra okullara yönetici seçimleri de yine yerel yönetimlerin sorumluluğundadır. Bulgaristan'da az sayıda olsa da devlete ait okullarda bulunmaktadır. Türkiye' de ise eğitim ile ilgili her türlü iş ve işlem yönetici atamaları dâhil Milli Eğitim Bakanlığı tarafından tek elden yürütülmektedir. Okulların yönetim faaliyetlerinde yerel yönetimler söz sahibi değildir. Hem Kanada'da hem de Bulgaristan'da okul müdürü olabilmek için yüksek lisans yapmak gerekmektedir. Ancak Türkiye için böyle bir koşul aranmamaktadır (Jones, 2014). Türkiye ve Bulgaristan' da hem eğitim bakanlıklarındaki merkezi denetim teşkilat yapısı hem de illerde bulunan denetim teşkilat yapısı birbirleri ile benzerlik göstermektedir. Ancak Kanada'da eğitim tamamen yerelden yürütüldüğü için merkezi bir yapı bulunmamaktadır. Eyaletlerde bulunan eğitim bölgelerindeki okul kurulları tarafından öğretmen değerlendirmeleri yapılmaktadır. Ayrıca hem Türkiye' de hem de Bulgaristan'da okullar bir bütün olarak değerlendirilmektedir. Bulgaristan'daki müfettişler ve Türkiye' deki müfettişler görevleri açısından birbirlerine benzemektedir. 
Hem Bulgaristan'da hem de Türkiye' de üniversiteler için akreditasyon merkezi vardır ancak Kanada'da her şey yerel düzeydeki bölgesel eğitim bakanlıkları tarafından yürütülmektedir ve akreditasyon yoktur. Kanada'da ulusal ve uluslararası sinavların önemi giderek artmaktadır. Okullar bu sınavlara göre değerlendirilmektedir. Öğretmenlerde dolayısıyla bu sınavlara öğrenci yetiştirme performansları ile değerlendirilmektedir. Kanada ve Türkiye'de sınıf denetimi ve öğretmen denetimi okul müdürleri tarafından yapılmaktadır (Parvanova, 2013; Taipale, 2012).

Özetle, her üç ülkede öğretmen yetiştirme açısından birbirine yakın uygulamalar olduğu, eğitim yöneticisinin özellikleri açısından Türkiye'de diğer iki ülkeden daha az eğitim ve niteliğe sahip olmanın yeterli olduğu, denetim açısından ise Kanada'da okul yöneticisine her yönüyle bırakılan denetimin, Bulgaristan'da eğitim bakanlığ1 denetçileri, Türkiye'de ise ders denetiminin okul yöneticileri, okul denetimlerinin ise eğitim bakanlığının atadığı müfettişler tarafından yürütüldüğü görülmektedir.

Eğitim ülkelerin en önemli önceliği olmak zorundadır. Bu da beraberin de tabiki gelişmeyi getirmektedir. Gelişmişliğin en belirgin özelliğinin de hiç kuşkusuz eğitimli insan gücü olduğu söylenebilir. Türkiye gibi gelişmekte olan ülkeler eğitim sistemlerinde yapacakları değişimi dünden bugüne anlık kararlarla değil, planlayarak yapmaları gelişmelerinde önemli olduğu söylenebilir. Bu gelişimi gerçekleştirirken diğer ülkelerin uygulamalarından da faydalanmanın, önemli bir unsur olduğu ifade edilebilir. Bunlar irdelenmeli, farklılık ve benzerlikler ortaya konularak, geniş bir yelpaze oluşturulmalıdır. Ancak her ülkenin kendine has dinamikleri olduğu kesinlikle unutulmamalı, eğitim sistemleri düzenlenirken buna dikkat edilmelidir.

Yukarıda anlatılanların ışı̆̆ında, araştırma sonuçları göz önüne alınarak bir takım öneriler getirilmiştir. Eğitim yönetiminin, eğitim biliminin en önemli alanlarından biri olduğu gerçeğinden yola çıkılarak, eğitim yöneticisi olabilmek için; en az yüksek lisans seviyesinde bir eğitim alınması, stajyer müdürlük kavramıyla hareket edilerek bir danışman müdür uygulaması getirilmesi ve uygun bir zaman diliminde bu stajyerlik eğitiminin danışmanlar tarafından verilmesi, sonunda da bir sınav yapılması ve uygulama dosyasından değerlendirme yapılması sağlanabilir. İkinci öğretim eğitim yönetimi yüksek lisans programları açılması için devlet tarafından üniversiteler finansal olarak desteklenebilir. Üniversitelerle işbirliği içerisine girilip, gerekli protokoller imzalanarak, mevcut yöneticilerin lisansüstü eğitim yapmaları sağlanabilir. Öğretmen adaylarının yerinde eğitim alabilmeleri için üniversite bünyelerinde uygulama okullarının yaygınlaştırılması sağlanabilir. Okul yöneticilerinin öğretmenlerin ders denetimini etkili bir şekilde yapabilmesi için uygulamalı eğitimler verilebilir. Okul denetimlerinin maarif müfettişleri tarafından daha etkili yapılabilmesi için "eğitim denetimi" yüksek lisans programları üniversiteler de açılabilir. Benzer araştırmalar aynı veya farklı ülkelerdeki özel okullarda yönetici olma sistemlerini karşılaştırarak yapılabilir. Aynı araştırma farklı ülkelerin eğitim sistemlerini veya bu araştırmada olduğu gibi öğretmen yetiştirme, eğitim yönetimi ve denetimi sistemlerini karşılaştırmak suretiyle yapılabilir. Öğretmen adayları, yöneticiler ve denetçiler üzerinde nitel araştırmalar yapılarak bu üç alanla ilgili zayıf ve kuvvetli yönler 
saptanabilir. Bu doğrultuda yine üç alanla ilgili olarak model geliştirme çalışmaları yapılabilir. Yerel yönetimlerde "eğitim kurulları" oluşturulmak ve yetkilendirilmek sureti ile eğitime daha fazla katılmaları sağlanabilir.

\section{Kaynakça}

Aykaç, N. ve Şahin, H. (2018). Comperative analysis of teacher education systems in Bulgaria, Poland, Russia and Turkey. Educational Process: International Journal, 7(7), 265-277.

Bakioğlu, A. ve Pekince, D. (2018). Kanada eğitim sistemi. Bakioğlu, A. (Ed.) Karşılaştırmalı Eğitim Yönetimi (s.157-195). Ankara: Nobel.

Chairoula, P. (2011). Ĕ̆itim denetimi Türkiye-Yunanistan-Bulgaristan Örneği. (Yayımlanmamış Yüksek Lisans Tezi). Trakya Üniversitesi, Edirne.

Copp, D. (2015). Teacher-based reactivity to provincical large-scale assessment in Canada. (Unpublished Doctoral Dissertation). Maastricht University, Canada.

Council of Ministers of Education Canada-CMEC (2008) Education In Canada. 14.08.2019 tarihinde https://www.cmec.ca/Publications/Lists/Publications/Attachments/64/Education-inCanada2008.pdf adresinden alınmıştır.

Delibaş, H. (2007). Türkiye, İngiltere, Almanya ve Finlandiya biyoloji öğretmeni yetiştirme programlarının karşılaştırılması. (Yayınlanmamış Yüksek Lisans Tezi). Ankara Üniversitesi, Ankara.

Erbilgin, E. ve Boz, B. (2013). Matematik Öğretmeni Yetiştirme Programlarımızın Finlandiya, Japonya ve Singapur Programları ile Karşılaştırması. Hacettepe Üniversitesi Eğitim Fakültesi Dergisi, 156-170

Ergen, H. ve Eşiyok, İ. (2017). Okul müdürlerinin ders denetimi yapmasına ilişkin öğretmen görüşleri. Çă̆daş Yönetim Bilimleri Dergisi, 3, 2-19.

Eurydice (2018). 30.12.2018 tarihinde https://eacea.ec.europa.eu/nationalpolicies/eurydice/content/bulgaria_en adresinden alınmıştır.

Günay, D. ve Gür, S. B. (2009). Dünyada üniversiteye giriş sistemleri ve ÖSS. Türkiye'nin 2023 Vizyonunda Üniversiteye Giriş Sistemi Kongresi, Sözel Bildiri, Atılım Üniversitesi, Ankara.

Gümüş, E. ve Bellibaş, M. Ş. (2015). Amerika Birleşik Devletlerinde ve Kanada'da okul müdürlerinin genel profili ve mesleki gelişim faaliyetlerine katılım düzeyleri. Mustafa Kemal Üniversitesi Sosyal Bilimler Enstitüsü Dergisi, 12(32), 158-179.

Huges, J., Laffier, J., Mamol, A., Morrison, L. Ve Petrarca, D. (2015). Re-imagining pre-service teacher education in Ontario,Canada: A journey in the making. Dublin Institude of Technolog, Higer Education Transformation Conference, Dublin 13.08.2019 tarihinde https://pdfs.semanticscholar.org/0b1b/8cb1487c3ff2227c810b7df01d075c540f2f.pdf adresinden alınmıştır.

İdin, Ş. (2012). Geçmişten günümüze öğretmen eğitimi ve ülkemize yansımaları. 1.ODTÜ Doktora Öğrencileri Çalıştayı, Sözel Bildiri, ODTÜ, Ankara.

Jones, G. A. (2014). An introduction to higher education in Canada. K. M. Joshi and Saee Paivandi (Ed.), Higher education across nations (1-38). Delhi: B. R. Publishing.

Kirbiy, D. (2007). Reviewing Canadian post-secondary education: Post-secondary education policy in post-industrial Canada. Canadian Journal of Educational Administration and Policy, $65,1-24$. 
Kinger, D. A., Shulha, L. M. ve Deluca, C. (2008). Teacher evaluation, accountability and professional learning: The Canadian Perspective. Rev. Pensamiento Educativo, 43, $209-222$.

Millî Eğitim Bakanlığı Eğitim Kurumlarına Yönetici Görevlendirme Yönetmeliği (2018). Resmi Gazete 21.06.2018 Tarih $30455 \quad$ Sayıll. 30.12.2018 tarihinde http://www.resmigazete.gov.tr/eskiler/2018/06/20180621-8.htm adresinden alınmıştır.

Millî Eğitim Bakanlığı Teftiş Kurulu Yönetmeliği (2017). Resmi Gazete 20.08.2017 Tarih 30160 Say1lı. 30.12.2018 tarihinde http://www.resmigazete.gov.tr/eskiler/2017/08/201708201.htm adresinden alınmıştır.

Millî Eğitim Bakanlığı Rehberlik ve Denetim Başkanlığı ile Maarif Müfettişleri Başkanlıkları Yönetmeliği Resmi Gazete 24.05.2014 tarih ve 29009 sayılı. 30.12.2018 tarihinde http://www.resmigazete.gov.tr/eskiler/2014/05/20140524-18.htm adresinden alınmıştır.

Millî Eğitim Bakanlığının Teşkilat ve Görevleri Hakkında Kanun Hükmünde Kararname (2011). Resmi Gazete 14.09.2011 Tarih 28054 Sayılı. 30.12.2018 tarihinde http://www.resmigazete.gov.tr/eskiler/2011/09/20110914-1.htm adresinden alınmıştır.

Milli Eğitim Temel Kanunu (1973). 30.12.2018 tarihinde http://www.mevzuat.gov.tr/ MevzuatMetin/1.5.1739.pdf adresinden alınmıştır.

Morgan, C. (2011). Educatin in Canada: Pursuit of educational quality and equity. Reviata Espanola de Educacion Comparada, 18, 125-156.

Mugo, P. ve Wolhuter, C. C. (2016). Concept, Types and Approaches to Comparative Education. T. Manichander içinde, Comparative Education (s. 1-49). Maharashtra: Laxmi Book Pub.

Özkan, H. H. ve Çelikten, Y. (2017). Milli eğitim sisteminin örgütsel yapısı ve maarif müfettişleri alt sisteminin işleyişi. Uluslararası Toplum Araştırmaları Dergisi, 7(13), 965-990.

Parvanova, Y. (2013). School manegement and school evaluation: a comparative analysis between Bulgarian and Japanese experience. 08.12.2018 tarihinde https://www.researchgate.net/publication/272574982_School_management_and_school_ evaluation_a_comparative_analysis_between_Bulgarian_and_Japanese_experience adresinden alınmıştır.

Pravitami (2018). 08.12.2018 tarihinde https:// pravitami.bg//10906 adresinden alınmıştır.

Psifidou, I. (2010). Training teachers in Bulgaria: Changing Learning Paradigms. In K. G. Karras \& C. C. Wolhuter (Eds.), International Handbook on Teacher Education Worldwide; Issues and Challenges. Athens: Atrapos Editions.

Taşdan, M. (2009). Kanada eğitim sistemi. Balcı A.(Ed.) Karşılaştırmalı eğitim sistemleri (363-376). Ankara: Pegem Akademi.

Tebliğler Dergisi (2018). 2735 Sayılı Tebliğler Dergisi. 30.12.2018 tarihinde https://ttkb.meb.gov.tr/meb_iys_dosyalar/2018_12/13170041_9_cizelgeveesaslar.pdf adresinden alınmıştır.

Türkiye'de Öğretmen Eğitimi ve İstihdamı (2017). Türkiye'de Öğretmen Eğitimi ve İstihdamı: Mevcut Durum ve Öneriler. Ankara: Hacettepe Üniversitesi Eğitim Fakültesi Dekanlığı 
30.12.2018 tarihinde http://www.egitim.hacettepe.edu.tr/belge/OgretmenEgitimiistihdam_Raporu.pdf adresinden alınmıştır.

Taipale, A. (2012). International survey on educational leadership. A survey on school leader's work and continuing education. Finnish National Board of Education and the Author, 12, 449.

Teftiş Kurulu Başkanlığı (2018). Türk eğitim sisteminde teftişin tarihi gelişimi 02.01.2019 tarihinde http://tkb.meb.gov.tr/www/turk-egitim-sisteminde-rehberlik-ve-denetimintarihsel-gelisimi/icerik/9 adresinden alınmıştır.

Türkoğlu, A. (1983). Fransa, İsveç ve Romanya Eğitim Sistemleri Karşılaştırmalı Bir Araştırma. Ankara: Ankara Üniversitesi Eğitim Bilimleri Fakültesi Yayınları, 121.

UNESCO (2006). 30.12.2018 tarihinde http://www.ibe.unesco.org/ sites/default/ files/ Canada.pdf adresinden alınmıştır.

Ültanır, G. (2000). Karşılaştırmalı Eğitim Bilimi Kuram ve Teknikler. Ankara: Eylül.

Yıldırım, A. ve Şimşek, H. (2005). Sosyal Bilimlerde Nitel Araştırma Yöntemleri. Ankara: Seçkin.

Yüksek Öğretim Kanunu (1981). 2547 Sayılı Kanun. 30.12 .2018 tarihinde http://www.yok.gov.tr/documents/37915040/38672190/2547+say\%C4\%B11\%C4\%B1\%20Y \%C3\%BCksek\%C3\%B6\%C4\%9Fretim+Kanunu.pdf/954efd63-dec8-4584-8bc9b3a58968f2da adresinden alınmıştır. 